\title{
PEER COUNSELING TRAINING AS A METHOD OF SEXUAL HEALTH PROMOTION IN ADOLESCENTS
}

\author{
Khoiriyah Isni \\ Faculty of Public Health, Ahmad Dahlan of University \\ J1. Prof. Dr. Soepomo, SH, Warungboto, Umbulharjo, Yogyakarta 55164, Indonesia \\ Correspondence address: Khoiriyah Isni \\ Email: khoiriyah.isni@ikm.uad.ac.id
}

\begin{abstract}
One characteristic of adolescents is their tendency to share information, tell stories, and gather with their peers. They may experience the negative effects of these habits when they do not have adequate life skills, especially in terms of sexuality. On the other hand, these activities present an opportunity for health promotion through peer-based approaches or peer counseling. The goal is to know the effects of peer counseling methods as media of information to increase adolescents' knowledge and attitude regarding sexual problems. The study used a quasi-experimental approach with a nonequivalent control group design. The sample consisted of 17 respondents between 15-24 years old living in Banguntapan, Bantul, Yogyakarta who fulfilled the inclusion and exclusion criteria. Data were collected with the purposive sampling technique. The research instrument used was a questionnaire. The results showed that there was a difference in the average knowledge level $(\mathrm{p}=0.021)$ and attitudes $(\mathrm{p}=0.000)$ of respondents related to sexuality before and after receiving peer counseling training. Methods and media used in delivering health information to adolescents should be diversified in schools, in the community, and in health services to generate interest in accessing and heeding appropriate health information.
\end{abstract}

Keywords: peer counseling, sexuality, adolescents, health promotion

\section{INTRODUCTION}

The most critical types of development during the adolescent stage are biological and psychological development. The development of sexuality is an essential bio-psycho-social development, during which adolescents begin to take on the role of an adult. During adolescence, a person's thoughts, perceptions, and responses are 'colored' sexually (Kar, Choudhury, and Singh, 2015). Reproductive behavior can stem from social interactions between men and women. These social interactions can lead to the forming of unwritten norms, values, and rules over a long period of time. These can then be used as a reference for reproductive behavior, which is usually in line with the norms, standards, and values that apply in society. There are expected and unexpected behaviors. Likewise, interactions between boys and girls during this stage relate to reproductive behavior. Reproductive behavior refers to sexuality and adolescent reproductive health, which can be influenced by various factors (Laksmiwiati, 2003).

Between 2011 and 2020, more than 140 million girls will become child brides, according to data from the United Nations Population Fund (UNFPA). If the current child marriage rate prevails, 14.2 million girls each year or 39,000 every day will marry underage. Furthermore, of the 140 million girls who will marry before they turn 18, 50 million will be under the age of 15 . Every year, about 21 million girls aged 15 to 19 years and 2 million girls under 15 years become pregnant in developing countries. Around 16 million girls aged 15 to 19 years and 2.5 million under the age of 16 give birth in developing areas yearly. This is a global problem that occurs in high, middle, and low- 
income countries. Worldwide, teenage pregnancies are more likely to occur in marginalized communities, generally driven by poverty and lack of education and employment opportunities (World Health Organization, 2018).

The government has a new benchmark in adolescent reproductive health, namely the difficulty of finding young people who are still virgins in large cities in Indonesia. A survey showed that more than $54 \%$ of adolescents in Surabaya claimed to have had premarital sexual relations. As many as $54 \%$ of adolescents in Medan, $47 \%$ of adolescents in Bandung, and 37\% of adolescents in Yogyakarta also claimed to have had sexual relations before marriage between the ages of 13-18 years (Anonimous, 2010). The survey results also show a variety of reasons for adolescent girls aged 15-24 to have premarital sexual relations. Their reasons included that it just happened $(38.4 \%)$ and they were forced by their partners $(21.2 \%)$. Meanwhile, the reasons put forward by teenage boys were they were curious $(51.3 \%)$ and it just happened $(25.8 \%)$. BKKBN research shows that eighty-four respondents experienced an unwanted pregnancy (KTD), and as many as $60 \%$ of them had an abortion (National Population and Family Planning Agency (BKKBN), 2012).

According to the Center for Sexuality Studies of the Indonesian Family Planning Association, there has been a change in adolescents' perspective of sexual behavior before marriage in Yogyakarta. 3.4\% of teenagers in Yogyakarta with male partners have had premarital sexual relations to have had premarital sexual relations. The Head of the Department of Secondary and Higher Education at the Yogyakarta Dikpora stated that, throughout 2013, there were 325 cases of unwanted pregnancy that occurred in adolescents (Thohari, 2013). Meanwhile, in the Bantul Regency, the rate of underage marriages has been high in the past five years. This can be attributed to the unexpected pregnancies. In 2014, the Bantul Regency was ranked second after the Gunung Kidul Regency in terms of numbers of early marriages. In 2010, there were 115 cases of marital dispensation, in 2011 were 145, in 2012 were 151, and in 2013 were 174 cases. There was a decline between 2013 and 2014, but the figures were still quite high for the Bantul Regency, which is not an urban area (Ariyanti, 2015).

When viewed in terms of health services, not all primary health services provide adolescent health services. Primary health services that have offered special health services for adolescents are considered not optimal in reaching young people. Additionally, primary health services with various limitations lead to social gaps between non-adolescent health care providers and their targets. Adolescents may then become reluctant to access adolescentspecific health services. This may lead to adolescents trying to find information themselves through their peers.

Problem-solving in adolescents is necessary to promote community empowerment and sexual and reproductive health promotion efforts. This is not only for the objective of adolescents receiving information, but also because adolescents play an active role and contribute by becoming peer counselors.

Peer counseling focuses on teenage relationships with each other. It also focuses on adolescent relationship patterns that can enhance their knowledge, attitude, behavior, and skills. Peer counseling is essential for adolescents. Adolescents more frequently discuss and review various issues with their peers than their parents, teachers, or mentors at school. Severe problems are no exception. They will only talk to adults when solving problems with peers is deadlocked. Teenagers have a strong sense of attraction 
and commitment, as well as the 'same boat' bond with their peers. Teenagers feel adults do not understand the problems they face, and only fellow teenagers can understand them. It is the closeness, openness, and similar feelings that create opportunities to improve knowledge, attitudes, behavior, and life skills through peer counseling training activities (Suwarjo, 2008).

Peer counseling allows teens to solve problems by receiving support from fellow teenagers. Peer counseling programs train and equip youth with skills to enable them to help their peers. Unlike professional counselors, peer counselors are available to help their colleagues at any time, and peer counseling sessions are informal discussions and conversations that are not threatening (Beatrice K et al, 2016).

Based on these problems, it is necessary to study the effect of peer counseling training on improving knowledge and attitudes of adolescents towards sexuality.

\section{METHODS}

This study used a quasi-experimental approach, with a nonequivalent control group design. The study was conducted in 2017 in Dukuh Karang Bendo, Banguntapan, Bantul, Yogyakarta. The selection of the research sample was based on recommendations from local stakeholders, namely the Hamlet Head, and it was adjusted according to the inclusion and exclusion criteria; therefore, the sampling technique used was purposive sampling. The inclusion criteria used in this study were teenagers aged 15-24 years, not married, and domiciled for a minimum of 6 months in the area of Karang Bendo Hamlet, Banguntapan, Bantul. Meanwhile, the exclusion criteria were to follow the research activities from start to finish and complete the pre-test and post-test questionnaires completely. Based on these criteria, a sample size of 17 respondents was obtained from 35 respondents.

Data collection was carried out twice, before and after peer counseling training was given. Peer counseling training was conducted by providing education and skills through lectures, discussions, case studies, and role-playing. The material provided included juvenile delinquency, reproductive health and adolescent sexuality, peer counseling skills, necessary communication skills, and communication through social media. What differed the peer counseling training in this study from other studies was the provision of the required communication skills, including communication through social media. The respondents were given training on how to frame health messages using 'youthful language' on social media.

Primary data were obtained by having the respondents fill out questionnaires containing questions related to the knowledge and attitude of adolescents towards sexuality issues. Data were tested using SPSS software version 17. Univariate data analysis verify by laying out the frequency distribution of each variable studied, i.e., demographics of respondents (age, sex, level of education, and occupation), their level of knowledge, and attitudes of respondents. Then, the Kolmogorov-Smirnov normality test was carried out to determine the normality of the data. The data normality test results state the data were normally distributed; therefore, the bivariate analysis utilized a paired-T test.

This study has received an Ethical Approval Letter from the Ahmad Dahlan University Research Ethics Committee with the number 021705083 , for health research that uses humans as research subjects.

\section{RESULTS}

The data were analyzed quantitatively using univariate and bivariate tests. Most 
respondents $(58.8 \%)$ were included in the early adolescent category (15-18 years), and $70.6 \%$ were male. Their level of education varied from the junior secondary level to the bachelors level. However, $47.1 \%$ of the respondents had completed or were undertaking secondary education (high school), and $23.5 \%$ were undertaking junior secondary education.

The internet, social media, and television were the primary sources for health information most commonly accessed by respondents $(94.1 \%)$. The secondary sources of data were parents, friends/relatives/neighbors, and newspapers/magazines/tabloids $\quad(88.2 \%)$, followed by radio $(82.4 \%)$. There were four respondents $(23.5 \%)$ who obtained health information from their campuses, both from lecture material and seminars.

The problems of reproductive health and sexuality are comprehensive, including relationships with the opposite sex. This study analyzed the relationship of respondents with the opposite sex. $47.1 \%$ of respondents claimed to have had a romantic relationship. Only $23.5 \%$ of the respondents who had had a romantic partner had their family and peers be aware of it. When they first dated varied greatly in ages starting from 15 years, 17 years, 18 years, and 21 years. The characteristics of respondents are presented in Table 1.

Tabel 1. Respondent Characteristics

\begin{tabular}{llcc}
\hline Respondent Characteristics & \multicolumn{1}{c}{ Category } & $\mathbf{N}$ & $\mathbf{\%}$ \\
\hline Age & Young Teenagers & 10 & 58.8 \\
& Older Teenagers & 7 & 41.2 \\
\hline \multirow{2}{*}{ Sex } & Male & 12 & 70.6 \\
& Female & 5 & 29.4 \\
\hline Education & Junior High School & 4 & 23.5 \\
& Senior High School & 8 & 47.1 \\
& Associate Degree & 2 & 11.8 \\
& Bachelor's degree & 3 & 17.6 \\
\hline Job & Student & 14 & 82.4 \\
& Worker & 3 & 17.6 \\
\hline
\end{tabular}

Source: Primary Data

The variables studied on when evaluating the effect of peer counseling training were the respondents' level of knowledge and attitudes towards sexuality. Measurement of variables were taken through questions from the questionnaire filled out by respondents before and after peer counseling training.

The univariate test results showed that nearly half of the respondents (41.2\%) lacked knowledge about adolescent sexuality. This percentage decreased after being given peer counseling training (17.6\%). This result is in line with the attitude variable. A similar number of respondents $(41.2 \%)$ had a negative attitude towards adolescent sexuality problems prior to counseling training. This number decreased to $23.5 \%$ of respondents still having a negative attitude after undergoing peer counseling training. These results are presented in Table 2. 
Table 2. Univariate Analysis Results

\begin{tabular}{llcccc}
\hline \multicolumn{1}{c}{ Variable } & & Category & $\mathbf{N}$ & \% \\
\hline $\begin{array}{l}\text { Knowledge of sexuality } \\
\text { intervention (Pre-test) }\end{array}$ & before & the & Sufficient & 10 & 58.8 \\
\multicolumn{2}{l}{} & & Insufficient & 7 & 41.2 \\
\hline $\begin{array}{l}\text { Knowledge of sexuality after the intervention } \\
\text { (Post-test) }\end{array}$ & Sufficient & 14 & 82.4 \\
\hline $\begin{array}{l}\text { Attitudes towards sexuality } \\
\text { intervention (Pre-test) }\end{array}$ & before & the & Insufficient & 3 & 17.6 \\
\hline $\begin{array}{l}\text { Attitudes towards sexuality } \\
\text { intervention (Post-test) }\end{array}$ & after & the & Positive & 10 & 58.8 \\
\end{tabular}

Source: Primary Data

This study examined the effect of peer counseling training on the level of knowledge and attitudes of adolescents on sexuality. Before the bivariate analysis, the data normality test was performed. The data normality test aimed to determine whether the distribution of data was normal or not using the Kolmogorov-Smirnov test. Data were categorized as normal if their p-value was higher than 0.05 . The data normality test results stated the data were normally distributed as presented in Table 3.

Table 3. Data Normality Test Results

\begin{tabular}{lccc}
\hline \multicolumn{1}{c}{ Variables } & Mean & Z scores & P values \\
\hline Sexuality knowledge (pre-test) & 32.82 & 0.710 & 0.694 \\
Sexuality knowledge (post-test) & 34.94 & 0.860 & 0.451 \\
Attitudes towards sexuality (pre-test) & 58.12 & 0.586 & 0.883 \\
Attitudes towards sexuality (post-test) & 62.59 & 0.682 & 0.742 \\
\hline
\end{tabular}

Source: Primary Data

Table 4. Bivariate Analysis Results

\begin{tabular}{|c|c|c|c|c|c|}
\hline \multirow{2}{*}{ Variables } & \multirow{2}{*}{ Mean } & \multicolumn{2}{|c|}{ CI $(95 \%)$} & \multirow{2}{*}{$T$ count } & \multirow{2}{*}{ Sign. } \\
\hline & & Lower & Upper & & \\
\hline $\begin{array}{ll}\text { Sexuality knowledge } & \text { (before } \\
\text { and after intervention) } & \end{array}$ & -2.118 & -3.870 & -0.366 & -2.562 & 0.021 \\
\hline $\begin{array}{l}\text { Attitudes towards sexuality } \\
\text { (before and after intervention) }\end{array}$ & -4.471 & -6.395 & -2.546 & -4.924 & 0.000 \\
\hline
\end{tabular}

Source: Primary Data

Based on the data normality test results, the bivariate analysis fulfilled the requirements for using the paired t-test. The results of bivariate testing using the paired ttest showed a significant influence on the provision of peer counseling training methods to increase respondents' knowledge about adolescent sexuality $(\mathrm{p}=0.021)$. This also indicated that there were differences in the respondents' average knowledge about 
sexuality before and after the peer counseling training. This had a mean deviation of 2.118 (Table 4).

The attitude variable was measured twice, before and after the peer counseling training. The categorization of attitude variables was divided into two: positive attitude and negative attitude towards adolescent sexuality. The univariate analysis results showed that seven respondents $(41.2 \%)$ had negative attitudes towards teenage sexuality before being given peer counseling training. However, this number dropped to only four (23.5\%) after being given peer counseling training.

The results of the bivariate analysis using paired T-tests showed that the provision of interventions in the form of peer counseling training could significantly influence respondents' attitudes towards sexuality $(\mathrm{p}=0.000)$. This result also suggested that there were differences in the attitudes of respondents before and after being given peer counseling training. The mean deviation for attitude was 4.471.

Through the bivariate analysis using paired t-tests on the variables of respondents' knowledge and attitudes towards sexuality, it can be concluded that the provision of peer counseling training can increase the level of knowledge and change the attitudes among the respondents who were initially unknowledgable of and/or negative towards the issue.

\section{DISCUSSION}

Growth and development are a continuous and concurrent process that brings change to each individual. The development of sexuality begins as early as in intrauterine life after conception, and continues through childhood, adolescence, and adulthood until death. During infancy, there is no gender awareness. Children recognize their sex in early childhood; starting at the age of three, self-awareness about sexuality (gender roles and gender identity) develops during childhood. Adolescence is a transition phase during which the leading development of sexuality takes place. Puberty is achieved during adolescence, which is a significant marker of the development of sexuality. The hypothalamus-pituitary-gonad axis is crucial for sexual development during puberty. Youth is divided into three stages: early adolescence (10-13 years), middle adolescence (14-16 years), and late adolescence (17-19 years). Physical changes begin in early adolescence when individuals become very concerned about their selfimage. During puberty, cognitive development occurs; adolescents develop abstract thinking and reasoning. Emotionally, they develop self-identity during late adolescence. Social involvement, peer interaction, and sexual interest are also developed in this phase. Experiments for different behaviors are seen in early adolescents, risk-taking is seen in mid-teens, and assessment of their risk-taking is seen in later adolescents (Kar et al., 2015).

One of the biggest influences in adolescence is peers. Peer influence can lead to maladaptive behavior, including risky sexual behavior. Research shows that the use of internet chat rooms is where adolescents become most vulnerable to having sexual behavior triggered. Furthermore, adolescents may be more likely to engage in risky sexual activities when there is support or examples from their peers. Nearly three-quarters of girls and more than $85 \%$ of boys respond to risk in public than in private. Differences in sexual risk behavioral responses in adolescents can be influenced by gender, ethnicity, puberty development, and peer and cultural experiences (Laura et al, 2017).

The peer counseling training method relied on the respondents' activeness by using the lecture method, active discussion, 
frequently asked questions, and practice. During the training, the materials presented in peer counseling training activities covered adolescent delinquency, reproductive health and sexuality, necessary communication skills, and peer counseling skills. Provision of young delinquency materials, reproductive health, and adolescent sexuality used lecture methods, active discussion, questioning, and answering. Content for basic communication skills and peer counseling, in addition to using the lecture method, intense debate, and question and answer, also used the roleplay method. Roleplay is a method of learning by involving people directly to portray a character, intended to maximize communication skills. The respondents were divided into four groups and given cases to discuss solutions for the problem. Next, each group played a role in presenting the results of the discussion. Each group played the roles of client, counselor, and observer.

In line with other studies, sexuality knowledge of respondents in this study became significantly higher after the intervention (67.7\%). Significance was calculated to have a $\mathrm{Z}$ score of 4.82 (Amelia, 2014). Moreover, Harini's research mentioned that the peer counselor training method had a significant impact on increasing knowledge, changing attitudes, and increasing PIK KRM administrators (Harini, 2014).

Research involving two unrelated samples, which were the intervention group and the control group, showed that the intervention group experienced a significant increase in knowledge about HIV compared to the control group. This was followed by an increase in positive attitudes towards HIV in the intervention group in comparison to the control group. Meanwhile, HIV risk behaviors were significantly reduced in the intervention group. Differences in knowledge were observed during three periods of time, before the intervention, immediately after the intervention, and three months after the intervention. The interventions provided consisted of peer education (Ibrahim et al , 2012).

Other research states that reproductive and sexual health education, counseling, and contraception determination were very effective in increasing knowledge about sexuality and contraceptive use, and reducing teenage pregnancy. However, in health issues such as female circumcision, the interventions that can be used are community mobilization and women's empowerment, which aim to increase awareness of the adverse health consequences of female circumcision. This is done to reduce the prevalence of female circumcision (Salam et al., 2016).

Sexuality and adolescent reproductive health education conducted by peer counselors should be carried out in an environment that provides comfort and pleasure. Information submitted by peer counselors can be justified. Teenagers experience changes physically and psychologically. Providing guidance and appropriate information can prevent teens from the dangers of free sex. Peer counselors can be one of the solutions to many problems experienced by adolescents. For teens, friends are trusted people instead of parents. Thus, peer counselors' activities can increase adolescent knowledge about the dangers of free sex and how to avoid it (Husodo and Widagdo, 2008). Other research stated that the peer group was a social group consisting of a group of people of the same age who have the same interests, as well as are equal in education and social class. Peer groups are relevant because they tend to provide a means to make friends. Peer groups can provide social and emotional support. Besides that, they can also give an identity and sense of belonging in social groups, especially during adolescence (Peçi, 2017). 
Health education on issues such as HIV/AIDS can be done through youth empowerment. The method used in this case is peer counseling training, which aims to improve adolescent knowledge and skills. Knowledge and skills need to be continually enhanced among members of the youth group at the village level. This training is vital as an effort to overcome the problem of the high incidence of HIV/AIDS from an early age. Training is a form of health education that involves the learning process. The training is practice-based and functions to increase knowledge and skills outside the formal education system in a relatively short time (Fitrianingrum et al, 2018).

Green and Kreuter explain there are three main categories in influencing a person's behavior. One of these is knowledge. They introduce knowledge into one of the predisposing factors for the formation of new behavior, that is, an internal element of a person that influences behavioral change to conduct behavior following the knowledge acquired. Individuals need knowledge as a form of support in growing individual confidence, attitudes, and behavior every day. Knowledge can support individuals in acting (Green and Kreuter, 1999).

Another predisposing factor is attitude. Attitudes are formed as long as humans live and develop because humans are not born with individual attitudes or perspectives. Attitudes make humans perform actions specifically against an object. Attitude is a product of socialization, to which a person responds according to a stimuli received. Before people get information or see the purpose, attitudes are impossible to emerge. Although it can be said to precede action, attitude does not always precede effective action. Attitude is a factor that makes it easier for someone to act happy or unhappy about a particular object, which can include cognitive, affective, and will components.
Intrinsic and extrinsic factors influence an individual's attitude towards an object. Intrinsic factors include personality, intelligence, talents, interests, feelings, needs, and motivations. Extrinsic factors include environmental factors, education, ideology, economics, politics, and defense and security. In this study, most of the respondents were positive about adolescent sexuality. These positive attitudes were influenced by the respondents' individual factors, one of which was knowledge. If the respondents' level of knowledge had been classified as good, it can lead to good attitudes and behavior in responding to adolescent problems related to sexuality.

Increasing knowledge and attitudes of adolescents to encourage behavioral changes towards issues of sexuality and adolescent reproductive health requires support from schools. This can be done through approaches from the physical aspects, sexual behavior, and social and mental changes of adolescents that are incorporated into the school curriculum (Hatami et al, 2015). Education on sexuality and adolescent reproductive health is the shared responsibility of parents, schools, the community, and the government. At schools, teachers can separate male and female students during the process of delivering sexuality and reproductive health lesson. Collaboration is needed between teachers in schools, parents, the community, and the government in the implementation of this curriculum. At school, teachers need to be given training related to sexuality and adolescent reproductive health materials. Families at home need to provide reproductive health education. Then, the community needs to provide supervision for adolescents in the surrounding environment (Fitriana and Siswantara, 2018).

All sectors, including parents, schools, community institutions, religious institutions, the media, business, health service providers, 
and policymakers, have the responsibility to promote healthy sexuality in adolescents. Strong evidence shows that a comprehensive approach to sex education helps teens resist the pressure to have sex too early. This approach includes knowledge about sexuality, courtship, the opposite-sex, decision making, communication, methods of controlling unwanted pregnancy, and sexually transmitted infections. Comprehensive sexual education encourages adolescents to foster healthy and responsible relationships with mutual protection whenever they decide to become sexually active (Tulloch and Kaufman, 2013).

When compared with traditional education methods, peer education leads to more positive outcomes such as increasing adolescent knowledge about health issues and providing referrals to health services. Despite its strengths, this approach can have limitations that require further attention. The importance of adolescence and problems surrounding this period should be noted. The critical role of peer education in promoting adolescent health needs to be emphasized. A more comprehensive evaluation of this program is needed in terms of strengths and limitations. The effectiveness of peer education programs depends on the selection of educators and peer groups, the quality of education delivered by educators, the evaluation of the education process, and the collaboration of stakeholders, parents, and the community. The study proposed planned action programs at regional, national, and international levels, including the contents of reproductive health material (Azizi et al, 2016).

Adolescent reproductive health material is a priority for high school students. It follows the characteristics of adolescents, while the content included in the peer counseling module is as follows: adolescent reproductive organs and functions, maintenance of adolescent reproductive organs, puberty in adolescents, risky sexual behavior, drug use, and teenage life. Education and information on reproductive health needs to be given as early as possible in Indonesia. In this case, the BKKBN is implementing the GenRe (Generasi beRencana) program that can help youth obtain accurate sources of information about reproductive health through peer counseling. The reproductive health information in the Adolescent Reproductive Health module talks about three primary threats to adolescent reproductive health (three basic threats/Triad), including sexuality, HIV/AIDS, and drug abuse (Nurfazriah, Sunjaya, and Susanah, 2018).

Innovations in the methods and media used to deliver health information to adolescents need to be supported to attract the attention of and spur interest in adolescents to access specific health activities and services. It is hoped that this can increase the knowledge and attitudes of adolescents to ensure their behavior does not lead to negative things and they remain productive as teenagers.

\section{CONCLUSION}

Peer counseling training is influential as a medium for the delivery of information on sexuality in terms of adolescents' level of knowledge $(\mathrm{p}=0.021)$ and attitudes $(\mathrm{p}=$ 0.000) in Banguntapan, Bantul, Yogyakarta. Adolescents need health promotion methods and media that are proactive towards them in order to optimize their utilization.

\section{REFERENCES}

Amelia, C. R. (2014). Pendidikan Sebaya Meningkatkan Pengetahuan Sindrom Pramenstruasi pada Remaja Peer Education Improve Premenstrual Syndrome Knowledge in Adolescent. Jurnal Kedokteran Brawijaya, 28(2), 
$151-153$.

https://doi.org/http://dx.doi.org/10.21

776/ub.jkb.2014.028.02.17

Ariyanti, S. (2015). Early Marriage in Bantul is predominantly Unwanted Pregnancy. Tribun News.

Azizi, M., Hamzehgardeshi, Z., \& Shahhosseini, Z. (2016). Influential Factors for the Improvement of Peer Education in Adolescents: A Narrative Review. Journal of Pediatrics Review, In Press(In Press). https://doi.org/10.17795/jpr-7692

Beatrice Kelly, A., Charles Odongo, B., Obiero Mobegi, C., Jairo Aloka, P., \& Benjamin Nyareki, O. (2016). The Influence Of Peer Counselors Training On Their Effectiveness In Addressing Risky Sexual Behaviours Among Students In Public Secondary Schools In Kisii Central Sub-County. International Journal of Arts and Commerce, 5(5), 52-61.

Fitriana, H., \& Siswantara, P. (2018). Pendidikan Kesehatan Reproduksi Remaja di SMPN 52 Surabaya. The Indonesian Journal of Public Health, 13(1).

https://doi.org/http://dx.doi.org/10.20 473/ijph.v13i1.2018.110-121

Fitrianingrum, N. M., Supiyati, S., \& Sumarni, S. (2018). Pengaruh Pelatihan Konselor Sebaya pada Remaja Desa Purwobinangun Sleman Terhadap Pengetahuan dan Keterampilan Memberikan Konseling HIV/AIDS. Jurnal Kesehatan Vokasional, 3(2), 96. https://doi.org/10.22146/-.33873

Green, L. W., \& Kreuter, M. W. (1999). Health Promotion Planning, An Educational And Environmental Approach. Mountain View, California.: Mayfield Publishing Compan.

Harini, R. (2014). The Effects of Peer
Counselor Training on Knowledge, Attitudes, and Skills of PIK-KRM Board in Faculty of Health, University of Muhammadiyah Malang. Postgraduate Program of Nursing Science Program Faculty of Medicine, Gadjah Mada University, 326247.

Hatami, M., Kazemi, A., \& Mehrabi, T. (2015). Effect of peer education in school on sexual health knowledge and attitude in girl adolescents. Journal of Education and Health Promotion, 4, 78. https://doi.org/10.4103/22779531.171791

Husodo, B. T., \& Widagdo, L. (2008). Pengetahuan dan Sikap Konselor SMP dan SMA dalam Penyuluhan Kesehatan Reproduksi Di Kota Semarang. Makara Kesehatan, 12(2), 59-62.

https://doi.org/https://doi/org/10.745 4/msk.v12i2.297

Ibrahim, N., Rampal, L., Jamil, Z., \& Zain, A. M. (2012). Effectiveness of peer-led education on knowledge, attitude and risk behavior practices related to HIV among students at a Malaysian public university - A randomized controlled trial. Preventive Medicine, 55(5), 505-510.

https://doi.org/10.1016/j.ypmed.2012 .09 .003

Kar, S., Choudhury, A., \& Singh, A. (2015). Understanding normal development of adolescent sexuality: A bumpy ride. Journal of Human Reproductive Sciences, $\quad 8(2), \quad 70-74$. https://doi.org/10.4103/09741208.158594

Laksmiwiati, ida ayu alit. (2003). Transformasi Sosial dan Perilaku Reproduksi Remaja. Jurnal Studi Jender Srikandi, 3(1).

Laura Widman, Choukas-Bradley, S., Helms, 
S. W., \& Prinstein, M. J. (2017). Adolescent Susceptibility to Peer Influence in Sexual Situations Laura. Physiology \& Behavior, 176(1), 139148.

https://doi.org/10.1016/j.physbeh.20 17.03.040

National Population and Family Planning Agency (BKKBN). (2012). Policy Brief Remaja Pernikahan Dini. Direktorat Pemaduan Kebijakan Pengendalian Penduduk (Ditjakduk).

Nurfazriah, I., Sunjaya, D. K., \& Susanah, S. (2018). The Peer Counseling Model in Adolescents Reproductive Health for Senior High School Students. Global Medical \& Health Communication (GMHC), 6(3), 209219.

https://doi.org/10.29313/gmhc.v6i3.3 108

Peçi, B. (2017). Peer Influence and Adolescent Sexual Behavior Trajectories: Links to Sexual Initation. European Journal of
Multidisciplinary Studies, 4(3), 96. https://doi.org/10.26417/ejms.v4i3.p 96-105

Salam, R. A., Faqqah, A., Sajjad, N., Lassi, Z. S., Das, J. K., Kaufman, M., \& Bhutta, Z. A. (2016). Improving Adolescent Sexual and Reproductive Health: A Systematic Review of Potential Interventions. Journal of Adolescent Health, 59(2), S11-S28. https://doi.org/10.1016/j.jadohealth.2 016.05 .022

Suwarjo. (2008). Konseling Teman Sebaya (Peer Counseling) Untuk Mengembangkan Resiliensi Remaja. Universitas Pendidikan Indonesia.

Thohari, H. (2013). PKBI Sebut Terjadi 325 Kehamilan Tidak Diinginkan di Yogyakarta. Tribun Jogja.

Tulloch, T., \& Kaufman, M. (2013). Adolescent Sexuality. Pediatrics in Review, 34(1).

World Health Organization. (2018). Adolescent pregnancy. World Health Organization. 